www.nature.com/cdd

\title{
Mammary epithelial cell phagocytosis downstream of TGF- $\beta 3$ is characterized by adherens junction reorganization
}

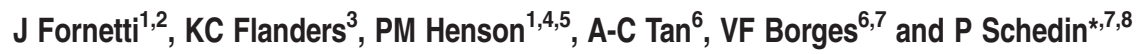

After weaning, during mammary gland involution, milk-producing mammary epithelial cells undergo apoptosis. Effective clearance of these dying cells is essential, as persistent apoptotic cells have a negative impact on gland homeostasis, future lactation and cancer susceptibility. In mice, apoptotic cells are cleared by the neighboring epithelium, yet little is known about how mammary epithelial cells become phagocytic or whether this function is conserved between species. Here we use a rat model of weaninginduced involution and involuting breast tissue from women, to demonstrate apoptotic cells within luminal epithelial cells and epithelial expression of the scavenger mannose receptor, suggesting conservation of phagocytosis by epithelial cells. In the rat, epithelial transforming growth factor- $\beta$ (TGF- $\beta$ ) signaling is increased during involution, a pathway known to promote phagocytic capability. To test whether TGF- $\beta$ enhances the phagocytic ability of mammary epithelial cells, non-transformed murine mammary epithelial EpH4 cells were cultured to achieve tight junction impermeability, such as occurs during lactation. TGF- $\beta 3$ treatment promoted loss of tight junction impermeability, reorganization and cleavage of the adherens junction protein E-cadherin (E-cad), and phagocytosis. Phagocytosis correlated with junction disruption, suggesting junction reorganization is necessary for phagocytosis by epithelial cells. Supporting this hypothesis, epithelial cell E-cad reorganization and cleavage were observed in rat and human involuting mammary glands. Further, in the rat, E-cad cleavage correlated with increased $\gamma$-secretase activity and $\beta$-catenin nuclear localization. In vitro, pharmacologic inhibitors of $\gamma$-secretase or $\beta$-catenin reduced the effect of TGF- $\beta 3$ on phagocytosis to near baseline levels. However, $\beta$-catenin signaling through $\mathrm{LiCl}$ treatment did not enhance phagocytic capacity, suggesting a model in which both reorganization of cell junctions and $\beta$-catenin signaling contribute to phagocytosis downstream of TGF- $\beta 3$. Our data provide insight into how mammary epithelial cells contribute to apoptotic cell clearance, and in light of the negative consequences of impaired apoptotic cell clearance during involution, may shed light on involution-associated breast pathologies.

Cell Death and Differentiation (2016) 23, 185-196; doi:10.1038/cdd.2015.82; published online 26 June 2015

Effective clearance of apoptotic cells is important in maintaining tissue homeostasis. Weaning-induced mammary gland involution is a unique model for studying apoptotic cell clearance, as $80-90 \%$ of the milk-producing mammary epithelium undergoes apoptosis to return the gland to a non-secretory state. ${ }^{1}$ Professional phagocytes, such as macrophages, are recruited into the involuting mammary gland; however, they are thought to have a limited role in the clearance of dying secretory cells, as in mice, peak macrophage infiltration occurs after the majority of apoptotic cell removal. $^{2}$ Rather, the neighboring mammary epithelial cells themselves appear to be the primary cell type responsible for apoptotic cell clearance during involution. ${ }^{2}$ Rapid and efficient apoptotic cell clearance is essential, as persistence of apoptotic cells can result in the release of cell fragments into the local environment and subsequent autoimmunity. ${ }^{3}$ Importantly, impaired apoptotic cell clearance in the postpartum mammary gland results in local inflammation, fibrosis and epithelial cell hyperplasia. ${ }^{4,5}$

Although there is increasing evidence that phagocytosis by mammary epithelial cells has a crucial role in maintaining tissue homeostasis in the involuting murine mammary gland, little is known about how mammary epithelial cells become phagocytic during postpartum involution. One of the key changes in the mammary epithelium that may contribute to acquisition of a phagocytic phenotype is reorganization of epithelial cell junctions. During lactation, tight junctions between mammary epithelial cells become highly

${ }^{1}$ Program in Reproductive Sciences, University of Colorado Anschutz Medical Campus, Aurora, CO, USA; ${ }^{2}$ Program in Immunobiology and Cancer, Oklahoma Medical Research Foundation, Oklahoma City, OK, USA; ${ }^{3}$ Laboratory of Cancer Biology and Genetics, National Cancer Institute, Bethesda, MD, USA; ${ }^{4}$ Department of Pediatrics, National Jewish Health, Denver, CO, USA; Integrated Department of Immunology, University of Colorado Anschutz Medical Campus, Aurora, CO, USA; ${ }^{6}$ Department of Medicine, Division of Medical Oncology, University of Colorado Anschutz Medical Campus, Aurora, CO, USA; ${ }^{7}$ Young Women's Breast Cancer Translational Program, University of Colorado Anschutz Medical Campus, Aurora, CO, USA and ${ }^{8}$ Knight Cancer Institute and Department of Cell, Developmental \& Cancer Biology, Oregon Health \& Science University, 3181 SW Sam Jackson Park Road, Portland, OR, USA

${ }^{*}$ Corresponding author: P Schedin, Knight Cancer Institute and Department of Cell, Developmental \& Cancer Biology, Oregon Health \& Science University, 3181 SW Sam Jackson Park Road, Mail Code L215, Portland, OR 97239, USA. Tel: +503 494 9341; Fax: +503 494 4253; E-mail: Schedin@ohsu.edu

Abbreviations: TGF- $\beta$, transforming growth factor- $\beta$; T $\beta$ RII, TGF- $\beta$ type II receptor; IHC, immunohistochemistry; RT, room temperature; TUNEL, terminal deoxynucleotidyl transferase dUTP nick end labeling; TEER, transepithelial electrical resistance; PBS, phosphate buffered saline; PAGE, polyacrylamide gel electrophoresis; GAPDH, glyceraldehyde 3-phosphate dehydrogenase; ZO-1, zona occludens-1; E-cad, E-cadherin; EMT, epithelial-to-mesenchymal transition; PS-1, presenilin-1; Psen1, presenilin-1 gene

Received 08.10.14; revised 31.3.15; accepted 14.5.15; Edited by M Piacentini; published online 26.6.15 
impermeable, which assures localization of milk within the mammary ducts. ${ }^{6}$ With weaning, this impermeability is lost, ${ }^{6}$ consistent with tight junction reorganization. Furthermore, reorganization of adherens junctions is also observed upon the switch from lactation to involution. ${ }^{7}$ Given that professional phagocytes such as macrophages do not exist in monolayers with cell cell junctions, disruption of epithelial cell junctions at the onset of mammary gland involution may be required for mammary epithelial cells to become phagocytic.

One candidate cytokine for promoting epithelial cell junction reorganization and phagocytosis is transforming growth factor- $\beta$ (TGF- $\beta$ ). Binding of TGF- $\beta$ to the TGF- $\beta$ type II receptor $(T \beta R I I)$ activates canonical signaling through a signaling cascade involving the TGF- $\beta$ type I receptor, receptor-associated Smads (Smad2/3) and Smad4. TGF$\beta$ protein and mRNA levels are significantly increased in the mammary gland on the switch from lactation to involution, with increased expression persisting through at least 9 days post weaning. ${ }^{8,9}$ Of the three TGF- $\beta$ isoforms (TGF- $\beta 1,-\beta 2$ and $-\beta 3)$, TGF- $\beta 3$ increases the greatest upon the lactation-toinvolution switch. ${ }^{8-11}$ Overexpressing TGF- $\beta 3$ or depleting Smad3 or $\mathrm{T} \beta \mathrm{R} I \mathrm{I}$ in the mammary epithelium reveals a necessary role for TGF- $\beta$ in promoting apoptosis early during involution. ${ }^{10,12-14}$ However, sustained TGF- $\beta$ expression throughout the postpartum involution window suggests additional roles for TGF- $\beta$ that extend beyond apoptosis induction, including influencing extracellular matrix remodeling and immune cell composition. . $^{8,12-15}$ TGF- $\beta$ is known to increase the phagocytic capacity of retinal pigment epithelial cells, fibroblasts and macrophages, ${ }^{16-18}$ although a role for TGF- $\beta$ in mediating apoptotic cell clearance by phagocytic mammary epithelial cells has not been explored. Furthermore, TGF- $\beta$ is implicated in tight junction disruption in the mammary gland and has known roles in adherens junction disassembly, making it an intriguing target to investigate in the promotion of a phagocytic phenotype in mammary epithelial cells. ${ }^{6,19}$

Currently, it is unknown whether the mammary epithelium has a role in apoptotic cell clearance in species other than mice. Therefore, we evaluated rat and human involution mammary tissue for apoptotic cell clearance by the mammary epithelium. Further, as addressing the role of TGF- $\beta$ in promoting phagocytosis by mammary epithelial cells during gland involution is challenging due to impaired cell death in the absence of TGF- $\beta$ signaling, ${ }^{12-14}$ we developed an in vitro model to investigate the role of TGF- $\beta 3$ in mammary epithelial cell junction reorganization and phagocytosis.

We demonstrate engulfment of apoptotic cells by mammary epithelial cells during weaning-induced involution in both rats and women, supportive of phagocytosis being a conserved feature of mammary epithelium during postpartum involution. Using our murine mammary epithelial culture model that mimics the high junctional resistance of the lactating gland, we show that TGF- $\beta 3$ promotes phagocytic capability and identify a potential role for cell-cell junction disruption in epithelial cell phagocytosis. Furthermore, we identify a previously unreported role for the intramembrane protease $\gamma$-secretase in the promotion of phagocytosis by TGF- $\beta 3$. In light of the negative consequences of impaired apoptotic cell clearance during postpartum involution, ${ }^{4,5}$ our data provide insight into how mammary epithelial cells may contribute to apoptotic cell clearance during this time.

\section{Results}

In mice, mammary epithelial cells have been identified as the primary phagocyte responsible for apoptotic cell clearance in the postpartum involuting mammary gland. ${ }^{2,4}$ To determine whether apoptotic cell clearance is a conserved function of mammary epithelium between species, dual fluorescent staining for apoptotic cell markers and the epithelium was performed using postpartum involuting mammary tissue from rats and women. In both species, increased apoptotic cell clearance by the alveolar mammary epithelium was observed during involution (Figures $1 \mathrm{a}-\mathrm{c}$ ), indicating conservation of phagocytosis by mammary epithelial cells in rat and human. Furthermore, during involution, human mammary epithelial cells upregulated the expression of the mannose receptor (Figure 1d), a scavenger receptor involved in engulfment. ${ }^{24}$ Mannose receptor expression by mammary epithelial cells during involution was transient and was detected in $100 \%$ of cases within 1 month of lactation cessation with gradual decline to $0 \%$ detection by 12 months postpartum (Figure 1e). This unique pattern of mannose receptor expression and the presence of apoptotic cells within the mammary epithelium are the first demonstration of a 'clearance' phenotype in human breast epithelium.

How mammary epithelial cells transition from a predominantly milk-secreting cell during lactation to function as a phagocyte during postpartum involution is unexplored. Based on reports of TGF- $\beta$ enhancing phagocytic ability in both professional and non-professional phagocytes, ${ }^{16-18}$ we hypothesize that TGF- $\beta$ promotes epithelial cell phagocytosis during involution. Supportive of this hypothesis, we observed increased TGF- $\beta$ protein in postpartum involuting rat mammary tissue (Figure $2 \mathrm{a}$ ), in agreement with previously reported murine data. ${ }^{8-11}$ TGF- $\beta$ was between 150 and $250 \mathrm{kDa}$, consistent with TGF- $\beta$ being in the latent complex. However, during involution, strong nuclear phospho-Smad2 ( $p$-Smad2) was observed, demonstrating increased active TGF- $\beta$ during involution. Further, nuclear $\mathrm{p}$-Smad2 was found within the mammary epithelium, but not within the stroma (Figure $2 b$ ), identifying mammary epithelial cells as highly TGF- $\beta$ responsive.

To test whether TGF- $\beta$ promoted phagocytosis by mammary epithelial cells, an in vitro mammary epithelium model was developed. Non-transformed murine mammary epithelial $\mathrm{EpH} 4$ cells were cultured at high density on transwell filters to form a polarized monolayer with functional tight and adherens junctions, demonstrated by zona occludens-1 (ZO-1) and E-cadherin (E-cad) localization at cell-cell contacts, respectively (Figure $3 \mathrm{a}$ ). In this model, the monolayer acquires high transepithelial electrical resistance (TEER), which is a functional readout of junction impermeability ${ }^{25}$ (Figure 3b). This mammary epithelium model mimics aspects of lactational epithelium in which tight junctions are well organized and highly impermeable. ${ }^{26}$ Following tight monolayer formation, $\mathrm{EpH} 4$ cells were treated for $24 \mathrm{~h}$ with TGF- $\beta 3$, which was chosen over other TGF- $\beta$ isoforms based on its increased abundance during early involution compared with TGF- $\beta 1$ (Figure $3 c$ and previous studies ${ }^{8-11}$ ) and our observation that 


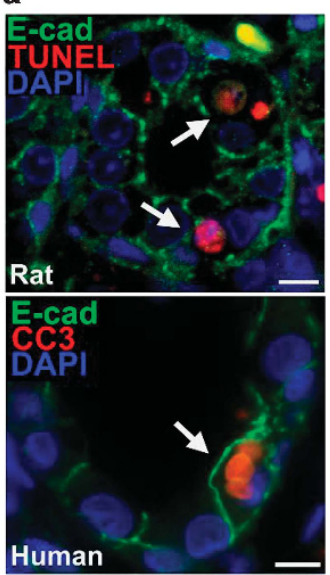

d

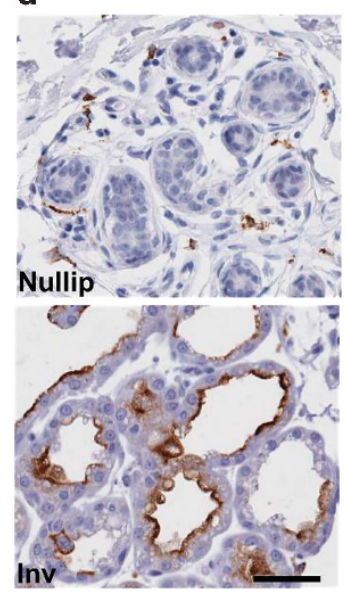

b

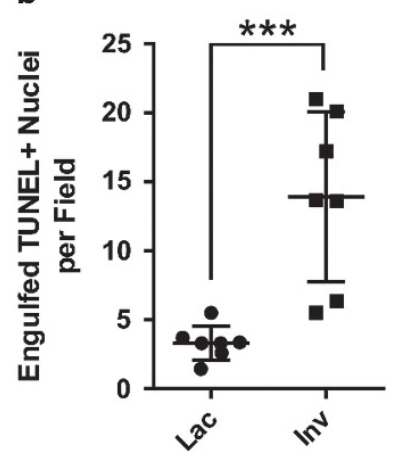

C

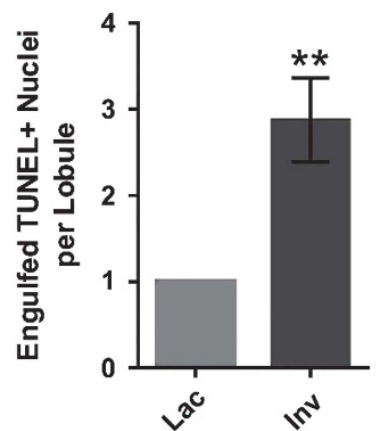

e

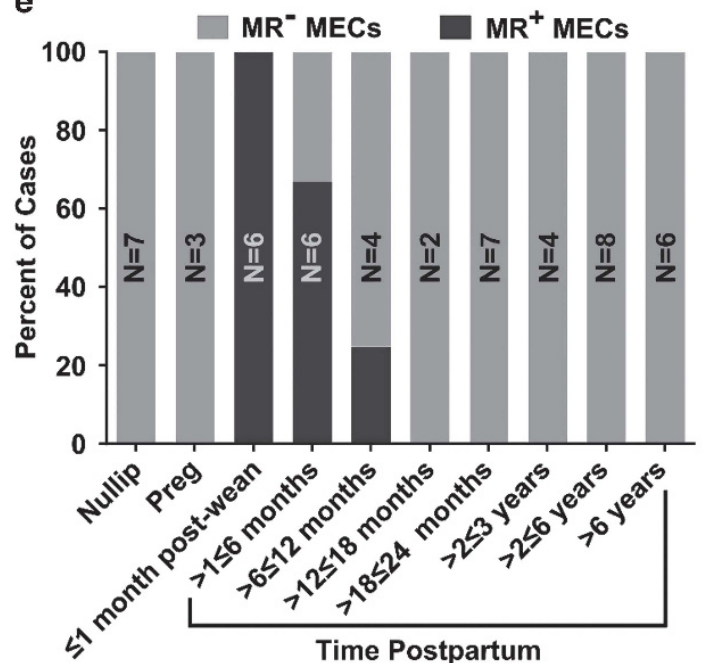

Figure 1 Phagocytosis is a conserved function of mammary epithelium in rat and human. (a) Apoptotic cells within mammary epithelial cells in rat (top) and human (bottom) tissue as demonstrated by dual staining for the epithelial cell marker E-cad (green) and the apoptotic cell markers TUNEL or cleaved caspase-3 (CC3) (red); arrows, apoptotic cells within epithelial cells; scale bar $=10 \mu \mathrm{m}$. (b) Quantification of TUNEL-positive nuclei within live mammary epithelial cells per 100x field in tissue isolated from lactating (Lac) or involution (Inv) day 4 rats; ${ }^{\star * \star} P<0.001$, two-tailed, unpaired $t$-test. (c) Quantification of TUNEL-positive cells within live mammary epithelial cells in lactational and involution lobules in breast tissue from women; ${ }^{*} P<0.01$, two-tailed, unpaired $t$-test ( $N=5$ cases). (d) Mannose receptor (MR) expression (brown) by mammary epithelial cells in human breast tissue from involuting (Inv), but not nulliparous (Nullip) women; scale bar $=50 \mu \mathrm{m}$. (e) Percentage of human cases with mannose receptor-positive mammary epithelial cells; Nullip, nulliparous; Preg, pregnant; MECs, mammary epithelial cells; $N$, number of cases/reproductive category

TGF- $\beta 2$ associates with lactation, but not involution (Supplementary Figure S2). After TGF- $\beta 3$ treatment, EpH4 cell monolayers were incubated with an enriched population of apoptotic cells, consisting of $\sim 64 \%$ apoptotic, $18 \%$ live and $18 \%$ necrotic cells (Supplementary Figure S3A), and positive for the apoptosis marker cleaved caspase-3 (Supplementary Figure S3B). Following TGF- $\beta 3$ treatment, an $\sim 4$-fold increase in apoptotic $\mathrm{EpH} 4$ cells was observed intracellularly within the live mammary epithelial cell monolayer (Figures $3 d$ and e). Labeled cells located within the live epithelial cell monolayer had fragmented nuclei or lacked detectable DNA. We did not find evidence for epithelial cell engulfment of live cells, as phagocytized cells with intact nuclei were not observed. These data are consistent with increased engulfment of apoptotic EpH4 cells by the epithelial cell monolayer following TGF- $\beta 3$ treatment. TGF- $\beta 3$ treatment also increased engulfment of carboxylated latex beads, a surrogate for apoptotic cells, ${ }^{27,28}$ which accumulate within the cytoplasm of the epithelial cells due to lack of degradation ${ }^{27,28}$ (Figures $3 f$ and g). Further, increased phagocytic ability following TGF- $\beta 3$ treatment was dose responsive (Figure 3 h). Importantly, as TGF- $\beta$ can induce apoptosis in non-transformed mammary epithelial cells, ${ }^{10,29}$ we confirmed that induction of apoptosis was not observed in $\mathrm{EpH} 4$ cell monolayers following $1 \mathrm{ng} / \mathrm{ml}$ TGF- $\beta 3$ treatment (Supplementary Figure S4). For subsequent phagocytosis assays, we used the $1 \mathrm{ng} / \mathrm{ml}$ TGF- $\beta 3$ dose.

Following TGF- $\beta 3$ treatment, EpH4 cell monolayers did not increase TEER (Figure $3 \mathrm{i}$ ) and had focal disruption of the tightjunction protein ZO-1 at the cell-cell interface (Figure 3j). Loss of tight junction integrity correlated with increased phagocytosis (Figure $3 \mathrm{k}$ ), suggesting a role for junction disruption in increasing the ability to phagocytose. To further investigate the role of cell junction disruption in epithelial cell phagocytosis, we evaluated adherens junctions. Following TGF- $\beta 3$ 
a

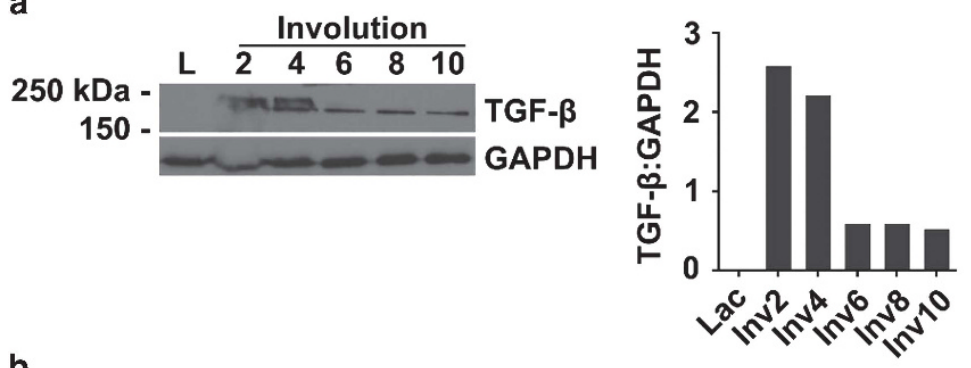

b
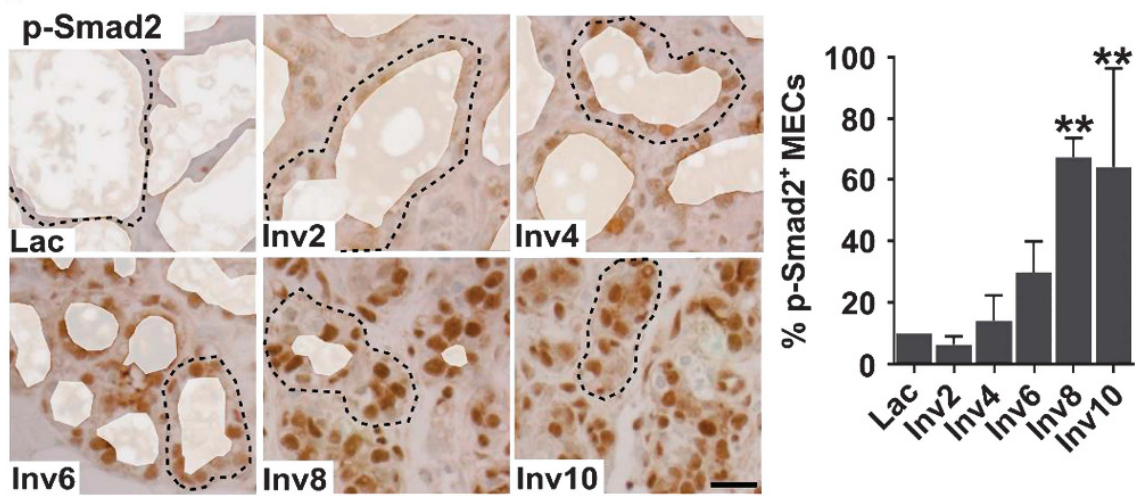

Figure 2 Increased TGF- $\beta$ signaling in the rat mammary gland during postpartum involution. (a) Immunoblot analysis (immunoblot, left panel; quantification, right panel) for TGF- $\beta$ using pooled rat mammary tissue lysate ( $N=6$ rats/stage) demonstrates increased TGF- $\beta$ between 150 and $250 \mathrm{kDa}$, consistent with latent TGF- $\beta$, during postpartum involution; Lac, lactation; Inv2-10, involution days 2-10. (b) Nuclear p-Smad2 (IHC staining, left panel; quantification, right panel), as a measure of TGF- $\beta$ signaling, increases in mammary epithelial cells during postpartum involution in the rat; dashed line = representative alveoli, alveolar lumens pseudocolored white to remove nonspecific staining of milk; scale bar $=20 \mu \mathrm{m},{ }^{\star \star} P<0.01$ versus lactation, Dunnett's multiple comparison's test $(\sim 14500$ total nuclei quantified)

treatment, $\mathrm{EpH} 4$ monolayers displayed decreased E-cad junctional staining and increased cytoplasmic localization, as well as increased E-cad cleavage (Figures $3 \mathrm{l}$ and $\mathrm{m}$ ). In addition, gene expression analysis revealed downregulation of multiple claudins, classical cadherns and cell adhesion molecules with TGF- $\beta 3$ treatment (Table 1), demonstrating global changes in cell junctions with acquisition of the phagocytic phenotype. In transformed epithelium, TGF- $\beta$ is known to induce cell junction disruption through activation of pathways involved in epithelial-to-mesenchymal transition $(E M T){ }^{30}$ therefore, expression of mesenchymal markers and transcription factors involved in EMT were evaluated. Notably, Snai1, Snai2, Twist1, Twist2, Zeb1, Vim and Fn1, genes highly associated with EMT, were not upregulated in $\mathrm{EpH} 4$ cell monolayers following TGF- $\beta 3$ treatment and, in fact, Zeb1 was significantly downregulated (Supplemental Table S3). These data indicate that the junctional changes in our phagocytic model are probably independent of TGF- $\beta$ induced EMT.

To determine whether E-cad reorganization occurs in vivo at the time of the phagocytic switch, as occurs in our in vitro model, E-cad localization was assessed in rat and human mammary tissue. In the nulliparous rat, mammary epithelial cells exhibited weak E-cad cytoplasmic and apical staining, and moderate to strong junctional staining (Figure 4a). During pregnancy, staining was primarily junctional, but at a lower intensity. Localization of E-cad to the lateral cell junctions was greatest during lactation (Figure 4a), consistent with the known junctional impermeability during this time. ${ }^{26}$ Following lactation, during early involution, E-cad relocalized to the apical cell surface (Figure 4a, Inv2-4, arrows) and in some cells was found to be strongly cytoplasmic (Figure 4a, Inv2-6, asterisk). E-cad junctional disruption was transient, as lateral cell junction localization was restored to nulliparous levels in the fully regressed gland (Figure $4 a$, Reg). In human breast tissue, E-cad was similarly localized primarily to the lateral cell junctions during lactation (Figure 4b, Lac panel), with apical (Figure 4b, Inv panel, arrow) and cytoplasmic localization during involution (Figure 4b, Inv panel, asterisk). Cumulatively, these data indicate that relocalization of E-cad away from lateral mammary epithelial cell junctions during involution is conserved in rats and humans. Further evidence of E-cadbased junction remodeling during involution was indicated by partial E-cad proteolysis specific to the involution time points (Figure 4c). E-cad cleavage during involution is reported to result in the release of the $\beta$-catenin-binding domain. ${ }^{7}$ To determine whether E-cad cleavage associated with relocalization of $\beta$-catenin away from the lateral epithelial cell junctions, $\beta$-catenin localization was evaluated in rat mammary tissue. Nuclear accumulation of $\beta$-catenin within the mammary epithelial cells was detected as early as involution day 4 and peaked at involution day 6 (Figure $4 d$ ). These data are consistent with $\mathrm{E}$-cad cleavage resulting in the release of $\beta$-catenin from the epithelial cell membranes during involution.

The release of the $\beta$-catenin-binding domain from E-cad has been shown to occur through cleavage of E-cad by the intramembrane protease $\gamma$-secretase; ${ }^{7}$ therefore, we investigated a role for $\gamma$-secretase in the rat involution model as well as in our in vitro phagocytic mammary epithelial cell model. In the rat mammary gland, $\gamma$-secretase activity increased from 


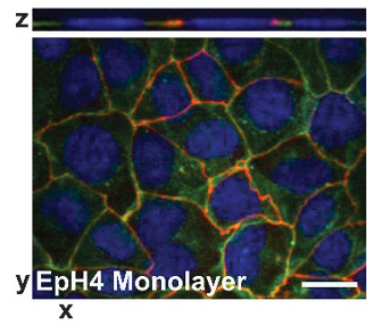

e
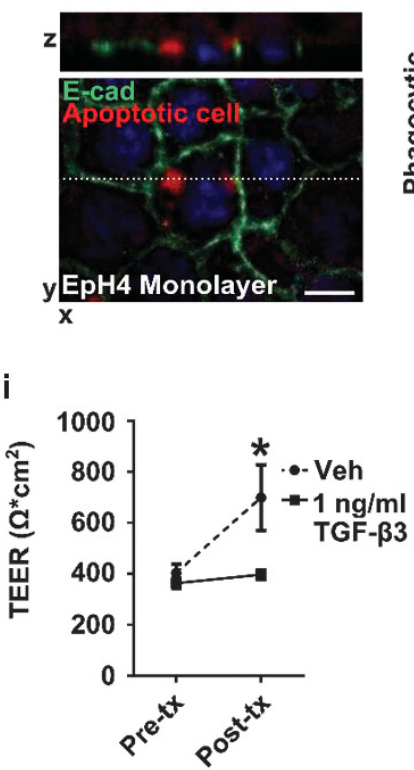

I

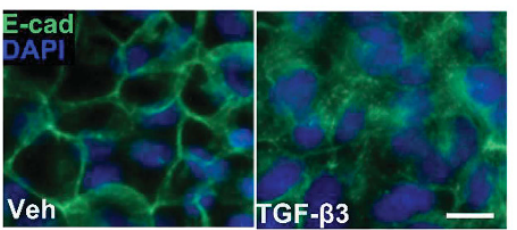

b

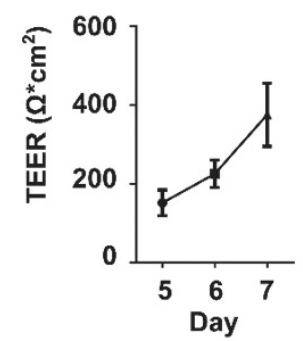

$\mathbf{f}$

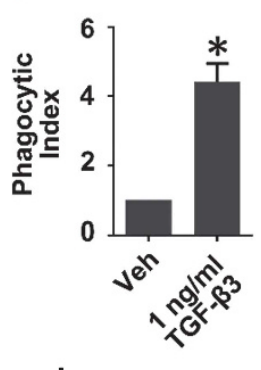

j

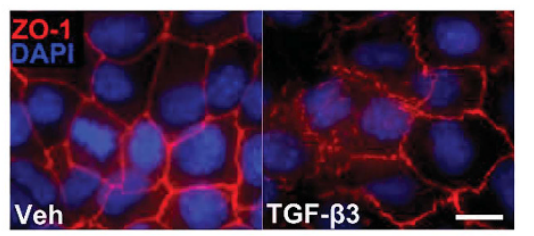

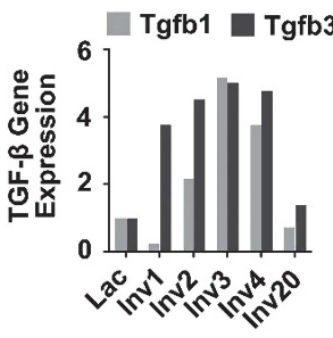

d

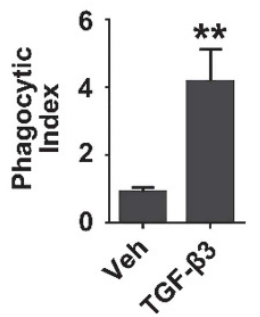

h

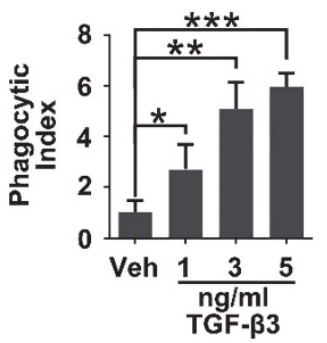

$\mathbf{k}$

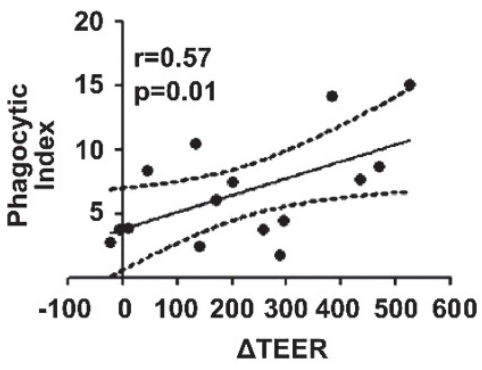

m

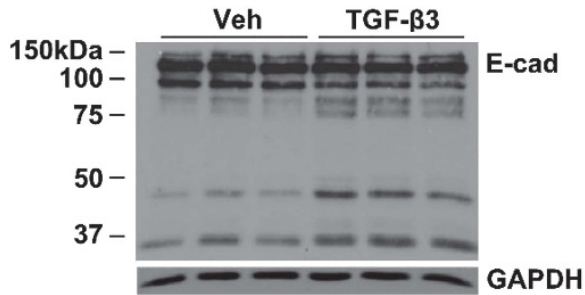

Figure 3 TGF- $\beta 3$ treatment leads to increased phagocytosis and cell-cell junction reorganization in mammary epithelial cell monolayers. (a) Localization of E-cad (green) and ZO-1 (red) to cell-cell junctions in EpH4 cell monolayers before TGF- $\beta 3$ treatment; scale bar $=10 \mu \mathrm{m}$. (b) Average TEER in EpH4 cell monolayers at 5,6 and 7 days post plating before treatment with TGF- $\beta 3$ ( $N=10$ experiments). (c) Analysis of publically available data sets demonstrates increased Tgbf3 gene expression before Tgfb1 in mouse mammary tissue. (d) TGF- $\beta 3$ ( $1 \mathrm{ng} / \mathrm{ml}$ ) treatment induces phagocytosis of apoptotic cells by EpH 4 cells; ${ }^{* *} P<0.01$, two-tailed $t$-test. (e) Engulfment of apoptotic cells labeled with CellTracker red (red) by EpH4 cells (E-cad, green) following $1 \mathrm{ng} / \mathrm{ml}$ TGF- $\beta 3$ treatment; dashed line, indicates level of z-stack; scale bar $=10 \mu \mathrm{m}$. (f) TGF- $\beta 3$ ( $1 \mathrm{ng} / \mathrm{ml})$ induces phagocytosis of carboxylated latex beads by EpH4 cells ( $N=13$ experiments); ${ }^{*} P<0.05$, one-sample, one-tailed $t$-test compared with vehicle set to 1 . (g) Engulfment of carboxylated latex beads (green spheres) by EpH4 cells following $1 \mathrm{ng} / \mathrm{ml} \mathrm{TGF}-\beta 3$ treatment; scale bar $=50 \mu \mathrm{m}$. (h) Enhanced phagocytosis of carboxylated latex beads with increasing doses of TGF- $\beta 3$; ${ }^{*} P<0.05,{ }^{* \star} P<0.01,{ }^{* \star *} P<0.001$, one-tailed $t$-test compared with vehicle ( $N=3$ wells per condition). (i) EpH4 cell monolayers fail to increase resistance following TGF- $\beta 3$ treatment; ${ }^{*} P<0.005$, two-tailed $t$-test ( $N=7$ experiments). (j) TGF- $\beta 3$ induces relocalization of ZO- 1 (red) away from cell-cell junctions; scale $\mathrm{bar}=10 \mu \mathrm{m}$. (k) Increased junction disruption following TGF- $\beta 3$ treatment (reported as the difference in TEER between vehicle- and TGF- $\beta 3$-treated cells $(\Delta \mathrm{TEER})$ associates with increased phagocytosis. (I) Increased E-cad cytoplasmic localization (green; scale bar $=10 \mu \mathrm{m}$ ) and cleavage $(\mathrm{m})$ following TGF- $\beta 3$ treatment

lactation to involution days 4 and 6 (Figure 5a). The $\gamma$-secretase enzyme complex consists of four known subunits-nicastrin, anterior pharynx-defective 1, presenilin (PS) enhancer 2 and PS. PS is the catalytic component of the complex, whereas the other three proteins serve as obligate co-factors. $^{31}$ Analysis of mouse microarray data sets ${ }^{32,33}$ demonstrated increased PS-1 gene (Psen1) expression in the mammary gland during involution (Figure 5b), consistent with increased $\gamma$-secretase activity during this time. In vitro, TGF- $\beta 3$ modestly, but consistently, increased Psen1 mRNA expression by EpH4 cell monolayers (Figure 5c), as well as PS-1 dimers and the C-terminal fragment (Figure $5 d$ ), which represent stable pools and active PS-1 protein, respectively. ${ }^{34,35}$ 
Table 1 Genes associated with cell junctions that are downregulated following TGF- $\beta 3$ treatment

\begin{tabular}{lccc}
\hline $\begin{array}{l}\text { Gene } \\
\text { symbols }\end{array}$ & Gene name & $\begin{array}{c}\text { Fold } \\
\text { change }\end{array}$ & P-value \\
\hline PCDHA11 & Protocadherin a11 & -1.22 & 0.010 \\
CDH18 & Cadherin 18 & -1.31 & 0.017 \\
CADM2 & Cell adhesion molecule 2 & -1.55 & 0.018 \\
CLDN17 & Claudin 17 & -1.35 & 0.020 \\
DSCAM & Down syndrome cell adhesion & -1.4 & 0.021 \\
CDH13 & molecule & -1.16 & 0.021 \\
CLDN14 & Cadherin 13 & -1.23 & 0.023 \\
CDH12 & Claudin 14 & -1.41 & 0.033 \\
$C D H 20$ & Cadherin 12 & -1.31 & 0.033 \\
$C D H 15$ & Cadherin 20 & -1.2 & 0.042 \\
$C D H 5$ & Cadherin 15 & 1.12 & 0.047 \\
\hline
\end{tabular}

Abbreviation: TGF- $\beta 3$, transforming growth factor- $\beta 3$

We next sought to determine whether $\gamma$-secretase activity and $\beta$-catenin signaling were required for induction of phagocytosis in the mammary epithelial cells following TGF$\beta 3$ treatment. This question was addressed using pharmacologic inhibitors. Inhibition of $\gamma$-secretase activity with DAPT ${ }^{36}$ or $L-685,458^{37}$ decreased phagocytosis following TGF- $\beta 3$ treatment (Figures $6 \mathrm{a}$ and $\mathrm{b}$ ), indicating that $\gamma$-secretase activity is required for increased phagocytic ability in our model. As $\gamma$-secretase cleavage of $\mathrm{E}$-cad can lead to the release of $\beta$-catenin from the cell membrane, we next sought to determine whether increased phagocytosis following TGF- $\beta 3$ treatment was $\beta$-catenin-dependent. Blocking $\beta$-catenin with the inhibitor $\mathrm{ICRT3}^{38}$ reduced phagocytosis downstream of TGF- $\beta 3$ by $\sim 60 \%$ (Figure $6 \mathrm{c}$ ), indicating a role for $\beta$-catenin in the increased ability of $\mathrm{EpH} 4$ cells to phagocytose following TGF- $\beta 3$ treatment. To address whether $\beta$-catenin signaling is sufficient to increase phagocytic ability, $\mathrm{EpH} 4$ cell monolayers were treated with $\mathrm{LiCl}$ at doses that induced $\beta$-catenin target genes Axin2 and Tcf7, but not Ccnd1 (Cyclin D1) (Figure 6d), which we speculate is due to $\mathrm{EpH} 4$ cells in a mature monolayer being non-proliferative. Induction of $\beta$-catenin signaling with $\mathrm{LiCl}$ treatment did not enhance phagocytic ability in this model (Figure 6e). These data suggest that although $\beta$-catenin signaling is needed for increased phagocytic ability, it is not sufficient. Based on these data, we propose a model in which increased phagocytic ability in the mammary epithelial cell monolayers following TGF-B3 treatment requires both junctional reorganization following $\gamma$-secretase cleavage of $\mathrm{E}$-cad as well as $\beta$-catenin signaling (Figure 6f).

\section{Discussion}

Deficiencies in apoptotic cell clearance during postpartum mammary gland involution have substantial negative consequences on tissue architecture and function. ${ }^{4,5,39}$ Upon the cessation of lactation, mammary epithelial cells lose their secretory phenotype, and-somewhat surprisingly-acquire phagocytic properties to function as the primary cell responsible for the clearance of dying secretory epithelial cells during postpartum involution. ${ }^{2}$ Currently, little is known about how mammary epithelial cells obtain phagocytic capacity to clear the gland of the immense number of apoptotic cells generated during involution. ${ }^{2,4}$ Here we describe a novel in vitro model for studying the induction of a phagocytic phenotype in mammary epithelial cells that permits the maturation of a polarized epithelium with impermeable tight junctions similar to those found in the mammary gland during lactation. ${ }^{6,26,40}$ TGF- $\beta 3$ treatment in this model increased phagocytic ability and recapitulates multiple aspects of the lactation to involution switch including TGF- $\beta$ signaling in the mammary epithelium, loss of tight and adherens junction integrity in an epithelial cell monolayer with previously established cell junctions, increased $\gamma$-secretase activity and increased phagocytosis by the epithelium. Our data unveil a previously undescribed role for TGF- $\beta 3$ in the enhancement of phagocytosis by mammary epithelial cells and implicate a mechanism dependent on $\gamma$-secretase and $\beta$-catenin. Furthermore, using clinical samples, we demonstrate that human breast epithelial cells function in apoptotic cell clearance during involution. Our in vivo finding that human breast epithelial cells express the mannose receptor specifically during the involution window provides further evidence that the mammary epithelium has a unique, phagocytic phenotype during this time. Mannose receptor is a scavenger receptor involved in the engulfment of glycoproteins, as well as opsinization-independent recognition and engulfment of bacterial, viral and fungal pathogens. ${ }^{24}$ Mannose receptor expression by the mammary epithelial cells raises the question of whether their phagocytic capacity extends beyond that of apoptotic cell engulfment to include clearance of milk constituents and host defense. ${ }^{24}$

Based on our in vivo and in vitro data, we predict that upon the switch from lactation to involution, TGF- $\beta 3$ induces $\gamma$-secretase activity, leading to $\mathrm{E}$-cad cleavage, release of $\beta$-catenin from the cell membrane, translocation of $\beta$-catenin into the nucleus and increased transcription of genes involved in phagocytosis (Figure 6f). In support of this model and consistent with our results, TGF- $\beta$ has been shown by others to increase the expression levels and activity of PS- $1,{ }^{41}$ and that PS-1 can cleave E-cadheren and promote $\beta$-catenin signaling. ${ }^{42}$ Our demonstration that two different $\gamma$-secretase inhibitors reduced TGF- $\beta 3$-induced phagocytosis suggests that loss of membranous $\beta$-catenin at the lactation to involution switch is dependent on $\gamma$-secretase enzyme activity. Our studies using the $\beta$-catenin activator $\mathrm{LiCl}$ suggest that induction of $\beta$-catenin signaling alone may not be sufficient to induce phagocytosis in mammary epithelial cells. However, a limitation to this study is that $\mathrm{LiCl}$ functions through inhibition of glycogen synthase kinase- $3 \beta$, which has a diverse array of proposed substrates in addition to $\beta$-catenin, ${ }^{43}$ and the effect of these other $\mathrm{LiCl}$ targets on inhibiting phagocytosis cannot be discounted. Furthermore, in addition to regulation of the $\beta$-catenin pathway, E-cad also influences the phosphatidylinositol-4,5-bisphosphate 3-kinase/Akt, Rho GTPase and nuclear factor $\kappa$ B pathways, all of which have been shown to have a role in phagocytosis in other models. ${ }^{44-47}$ Genetic ablation and constitutive activation approaches would directly test the roles of $E$-cad cleavage and $\beta$-catenin signaling in the induction of the phagocytic phenotype. However, transient transfections of mature, electrically resistant $\mathrm{EpH} 4$ cell monolayers were unsuccessful and permanent genetic manipulation of these adhesion proteins can prevent the 
a

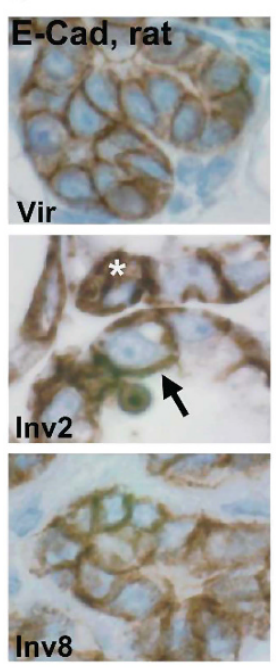

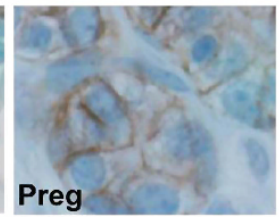
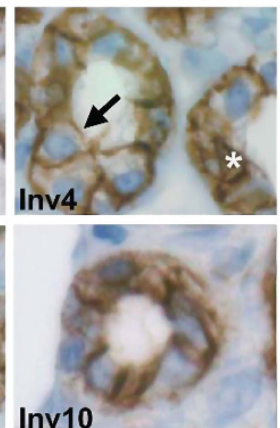

Inv10
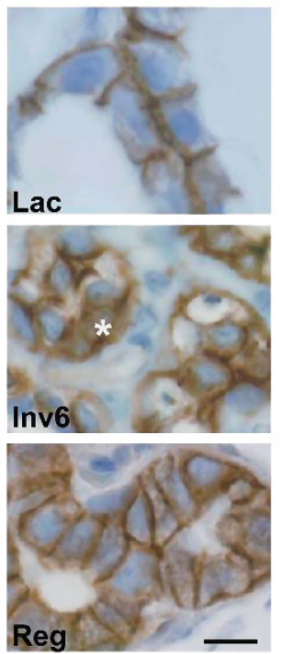

b

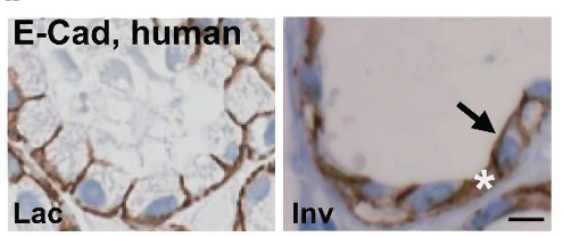

c

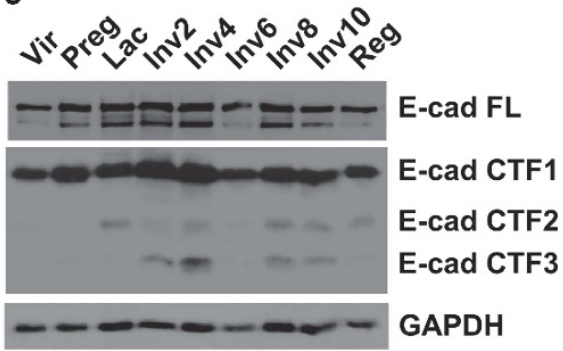

d
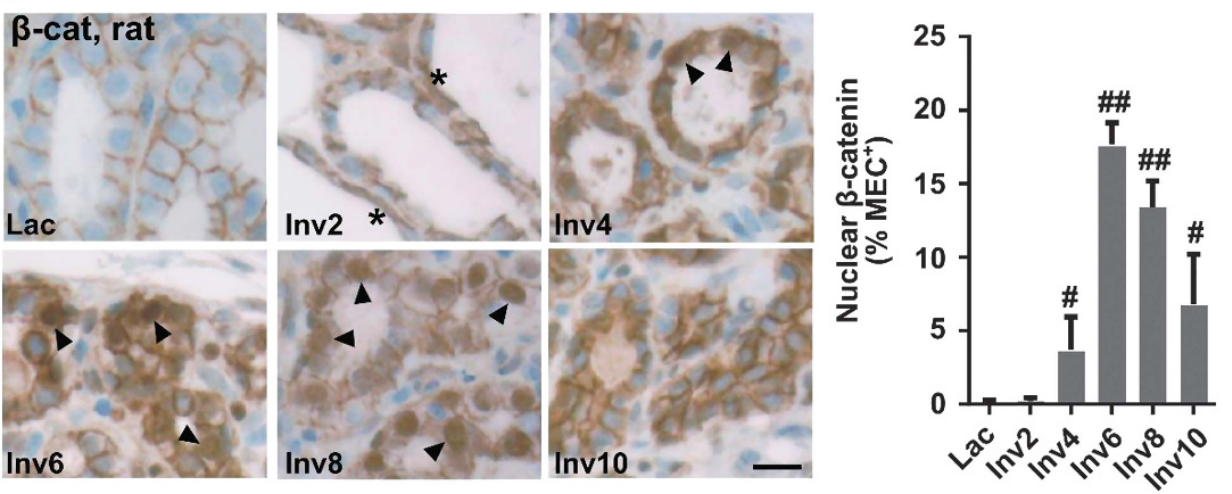

Figure 4 Mammary epithelial cell adherens junctions reorganize during postpartum involution. (a) Representative IHC images of rat mammary tissue E-cad show increased apical (arrow) and cytoplasmic (asterisk) localization during postpartum involution; Vir, virgin; Preg, pregnant; Lac, lactation; Inv2-10, involution days 2-10; Reg, regressed; scale bar $=10 \mu \mathrm{m}$. (b) Increased apical (arrow) and cytoplasmic (asterisk) E-cad observed in human involution breast tissue; scale bar $=20 \mu \mathrm{m}$. (c) Increased fragmentation of E-cad in rat mammary tissue during postpartum involution (lysates pooled from six rats/stage); FL, full length; CTF1-3, C-terminal fragment 1-3. (d, left panel) IHC images of $\beta$-catenin ( $\beta$-cat) show increased cytoplasmic (asterisk) and nuclear (arrow head) localization during postpartum involution in the rat mammary gland; scale bar $=20 \mu \mathrm{m}$. (d, right panel) Quantification of $\beta$-catenin IHC images; MEC, mammary epithelial cells, \#P<0.05, \#\#P<0.0001; one-tailed $t$-test compared with lactation ( 31000 nuclei quantified)

formation of mammary epithelial monolayers with functional junctions. ${ }^{49,50}$ For example, E-cad cleavage by $\gamma$-secretase requires binding of PS-1 to residues 604-615 of the mature processed E-cad. ${ }^{37,48}$ Thus, although mutants lacking this region of E-cad cannot be processed by $\gamma$-secretase, loss of these residues also prevents proper formation of adherens junctions, precluding the use of such a mutant in the model described here. ${ }^{37,49}$ Likewise, expression of the cytoplasmic domain of E-cad functions in a dominant-negative manner to disrupt the normal structure of both adherens and tight junctions, indicating that this approach is also not able to be used to investigate the potential role of the cytoplasmic E-cad fragment generated by $\gamma$-secretase cleavage in phagocytosis. ${ }^{50,51}$

The work described here raises intriguing questions regarding the role of phagocytic mammary epithelial cells in vivo. The correlation between decreased junctional integrity and increased phagocytic capacity indicates that the loss of cell junctions may be an important step in mammary epithelial cells becoming phagocytic upon the switch from lactation to involution; however, cell junctions are tighter during lactation than any other stage, begging the question of whether or not mammary epithelial cells are normally phagocytic, except for during lactation. Given that the mammary epithelium undergoes small cycles of proliferation and apoptosis in response to ovarian hormone cycling, ${ }^{52}$ it is possible that mammary epithelial cells also function in apoptotic cell clearance to maintain tissue homeostasis in the non-pregnant, premenopausal state. However, mannose receptor expression by mammary epithelial cells in human breast tissue exclusively during early involution suggests that even if mammary epithelial cells have a basal phagocytic capacity, they obtain a unique phagocytic phenotype during postpartum involution. Murine models using up-the-teat injections of carboxylated latex beads, apoptotic cells and other targets of engulfment will provide further insight into the extent of the phagocytic capacity of the mammary epithelium across reproductive stages.

Further understanding of how mammary epithelial cells become phagocytic is of interest as deficiencies in apoptotic 


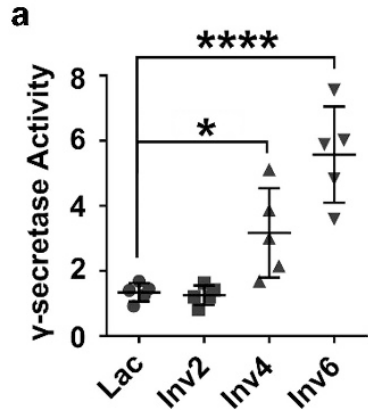

b

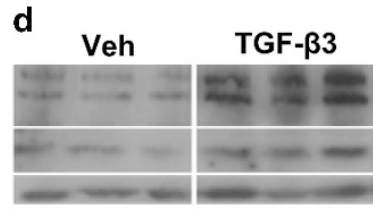

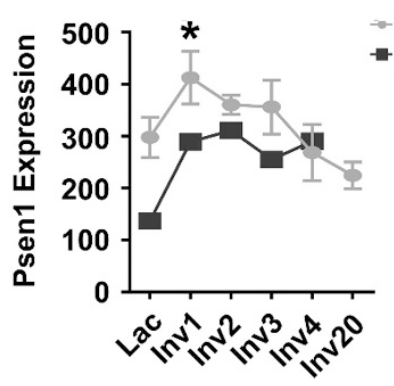

C

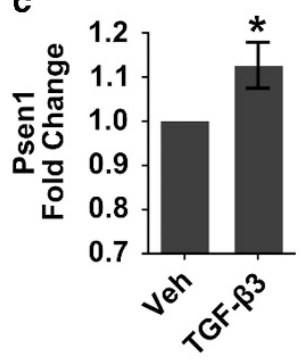

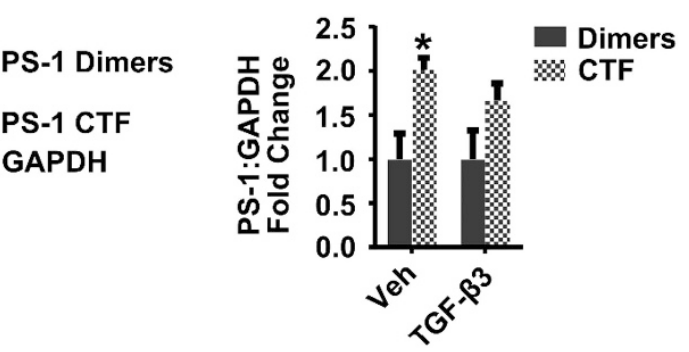

Figure 5 Evidence for increased $\gamma$-secretase activity during involution in vivo and following TGF- $\beta 3$ treatment in vitro. (a) Increased $\gamma$-secretase activity in rat mammary tissue lysate during postpartum involution. Data are reported as fluorescent units normalized to GAPDH, as described in Methods; ${ }^{*} P<0.05,{ }^{* * * *} P<0.001$ Dunnett's multiple comparison test. (b) Increased Psen1 gene expression in the mouse mammary gland during early stages of postpartum involution, using two publically available data sets. Data set 1 error bars $=$ S.D., $N=3, P<0.05$ versus lactation, Dunnett's multiple comparison's test. (c) TGF- $\beta 3$ induces a modest increase in Psen 1 expression in EpH4 cell monolayers; ${ }^{*} P<0.05$, one-sample, two-tailed $t$-test compared with 1 ( $N=3$ experiments). (d) Increased PS-1 dimers and C-terminal fragment (CTF) in EpH4 cell monolayers following TGF- $\beta 3$ treatment (Immunoblot, left panel; quantification, right panel), ${ }^{*} P<0.05$, two-tailed $t$-test ( $N=3$ experiments)
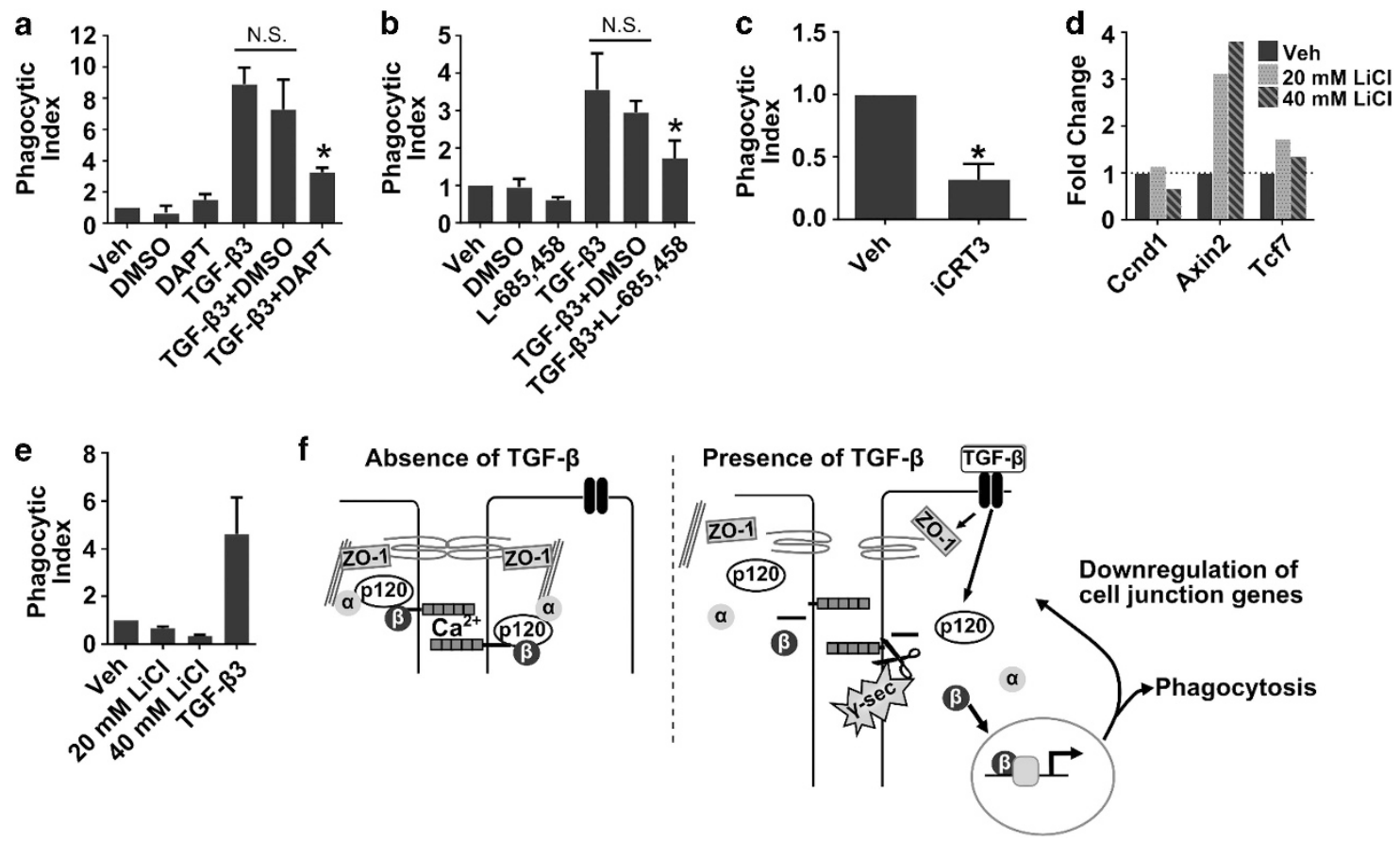

Figure $6 \gamma$-Secretase and $\beta$-catenin mediate TGF- $\beta 3$-induced phagocytosis in EpH4 cells. Inhibition of $\gamma$-secretase with DAPT (a) or L-685,458 (b) reduces TGF- $\beta 3$-induced engulfment of carboxylated beads; two-tailed $t$-test, ${ }^{*} P<0.05$ versus TGF- $\beta 3+D M S O$, n.s. $=$ non-significant. (c) Inhibition of $\beta$-catenin with the inhibitor iCRT3 reduces TGF- $\beta 3$ induced engulfment of carboxylated beads, ${ }^{*} P<0.05$, one-sample, two-tailed $t$-test. ( $N=3$ experiments). LiCl treatment induces expression of $\beta$-catenin target genes (d), but is insufficient to induce phagocytosis (e). $N=3$ experiments. (f) Proposed model of phagocytosis induction in mammary epithelial cells. In the absence of TGF- $\beta$ signaling (left panel), cell-cell tight and adherens junction are intact (left panel). In the presence of TGF- $\beta$ signaling, there is decreased integrity of cell-cell junctions and $\gamma$-secretase cleavage of $\mathrm{E}$-cad, both of which are necessary for induction of phagocytosis. Following E-cad cleavage, $\beta$-catenin is freed from the cell membrane, allowing it to move to the nucleus where it activates transcription of genes involved in the acquisition of a phagocytic phenotype and may contribute to downregulation of cell junction-associated genes 
cell clearance during postpartum involution lead to increased macrophage infiltration, collagen deposition, vascularization and epithelial proliferation. ${ }^{4,5,39}$ These stromal changes and hyperproliferative epithelium are similar to the changes observed with ductal carincoma in situ of the breast, leading to the speculation that defective apoptotic cell clearance may provide a catalyst for breast cancer development. ${ }^{53-57}$ In addition, the immunosuppressive immune milieu associated with clearance of apoptotic cells by the mammary epithelium has also been proposed to contribute to breast cancer progression. ${ }^{58,59}$ Women have a transient increase in breast cancer risk during the postpartum period and breast cancers diagnosed postpartum have poor prognosis. ${ }^{60,61}$ In preclinical postpartum breast cancer models, postpartum tumors are associated with increased immune-suppressive cytokines, macrophages and regulatory T cells. ${ }^{62,63}$ Apoptotic cell clearance by the macrophages can promote production of the immune-suppressive Th2 cytokines IL-4, IL-10 and TGF- $\beta 1,{ }^{63-66}$ supporting the hypothesis that apoptotic cell clearance during postpartum involution promotes an immune-suppressive microenvironment that allows tumor cells to escape immune surveillance and metastasize. ${ }^{58,59}$ Consistent with this hypothesis, Standford et al. ${ }^{63}$ demonstrated decreased immunesuppressive macrophages and a dramatic reduction in metastasis following inhibition of the apoptotic cell receptor MerTK in postpartum mouse mammary tumors. However, the effects of MerTK inhibition on the primary tumor cells were not addressed in this model and cannot be discounted, as MerTK upregulation is observed in metastatic breast cancers ${ }^{67}$ and MerTK can mediate cancer cell invasion in vitro. ${ }^{68,69}$ The potential roles for apoptotic cell clearance in breast cancer promotion and the increased risk for poor-prognosis breast cancers during the postpartum period highlight the need for in vitro models, such as the one described here, which can be used to further understand mechanisms involved in apoptotic cell clearance by the mammary epithelium, subsequent consequences on the local microenvironment and breast cancer development.

\section{Materials and Methods}

Human tissue acquisition. Under protocols approved by the University of Colorado Institutional Review Board, 53 breast tissue specimens were obtained from premenopausal women aged 21-45 years, who underwent clinically indicated biopsy $(n=2)$ or surgery $(n=51)$. Histologically normal tissue was identified by pathologic review and analyzed an average of $>8 \mathrm{~mm}$ away from the cancer. Based on patient histories, cases were stratified into the following reproductive categories: nulliparous $(n=7)$, pregnant $(n=3), \leq 1$ month postlactation $(n=6),>1$ month and $\leq 6$ months postpartum $(n=6),>6$ months and $\leq 12$ months postpartum $(n=4),>12$ months and $\leq 18$ months postpartum $(n=2),>18$ months and $\leq 24$ months postpartum $(n=7),>24$ months and $\leq 3$ years postpartum $(n=4),>3$ years and $\leq 6$ years postpartum $(n=8)$, and $>6$ years postpartum $(n=6)$

Animal husbandry, reproductive staging and tissue preparation. Animal procedures were approved by the University of Colorado Anschutz Medical Campus Institutional Care and Use Committee. Sprague-Dawley rats (Harlan Laboratories, Indianapolis, IN, USA) 70 days of age were bred, normalized to six pups per dam at 2 days post-parturition and mammary tissue collected at the following reproductive stages as described: ${ }^{20}$ age-matched virgin; pregnant (days 18-20); lactation (days 10-11); involution day 2, 4, 6, 8 and 10 (2-10 days postwean); and fully regressed (4 weeks post-wean).
Immunohistochemical and TUNEL staining, image acquisition and quantification of breast and mammary tissues. For human and rodent tissue, 4- $\mu \mathrm{m}$-thick, formalin-fixed paraffin-embedded sections were deparaffinized and rehydrated. For immunohistochemical $(\mathrm{IHC})$ staining, except p-Smad2, sections were subjected to antigen retrieval $\left(125^{\circ} \mathrm{C}\right.$ under pressure for $5 \mathrm{~min}$ ) and sequentially incubated in $3 \% \mathrm{H}_{2} \mathrm{O}_{2}$ in methanol (room temperature (RT), $5 \mathrm{~min}$ ), Protein Block (RT, $10 \mathrm{~min}$; Dako, Carpinteria, CA, USA), primary antibody (RT, $1 \mathrm{~h}$ ), secondary antibody (RT, $30 \mathrm{~min}$ ), 3,3'-diaminobenzidine (RT, $10 \mathrm{~min}$; Dako) and hematoxylin (RT, 6 min; Dako). See Supplementary Table S1 for specific antigen retrieval and antibody information. p-Smad2 staining was performed as described. ${ }^{21}$ For dual E-cad and TUNEL (terminal deoxynucleotidyl transferase dUTP nick end labeling) staining of rat tissue, E-cad IHC was performed followed by TUNEL staining using the TACS 2-TdT-Fluor In Situ Apoptosis Detection Kit (Trevigen, Gaithersburg, MD, USA) with the $\mathrm{Mn}^{2+}$ cation at a final concentration of $1 \times$ as per the manufacturer's instructions. Fluorescent images were acquired using an Olympus IX81 inverted microscope and Slidebook v.4.067 software (Intelligent Imaging Innovations, Denver, CO, USA). For TUNEL staining of human tissue, the TACS 2-TdT-DAB In Situ Apoptotic Detection Kit (Trevigen) was used with the $\mathrm{Co}^{2+}$ cation at a final concentration of $1 \times$ as per the manufacturer's instructions. For rat tissue, quantification of apoptotic cell clearance by mammary epithelial cells was performed by counting the number of TUNEL+ nuclei within the mammary epithelium in ten $100 \times$ fields per rat ( $N=7$ rats per stage). For human tissue, the number of TUNEL+ nuclei within the mammary epithelium was counted in 7-10 lactation lobules and 7-10 involution lobules within the same case ( $N=5$ cases) in breast tissue of women who were within 6 weeks post-lactation. For each case, the data are reported relative to lactation. Images of mannose receptor-stained tissue were achieved by extracting regions from whole-slide images that were acquired using a ScanScope T3 scanner (Aperio Technologies, Vista, CA, USA) at $0.46 \mu \mathrm{m}$ per pixel. Owing to heterogeneous mannose receptor expression in the alveolar epithelium across a single case, quantification of mannose receptor expression by mammary epithelial cells was performed by determining whether or not each case had any mannose receptor-positive mammary alveoli. In cases without mannose receptor staining in the mammary epithelial cells, evidence that the staining worked was provided by identifying positive stromal cells. For E-cad, $\beta$-catenin and $\mathrm{p}$-Smad2, light microscopy images were acquired using a Zeiss Axioskop (Zeiss, Thornwood, NY, USA) and SPOT RT3 camera (SPOT Imaging Solutions, Sterling Heights, MI, USA). Quantification of nuclear $\beta$-catenin was performed by counting the total number of epithelial nuclei and determining the percentage that were $\beta$-catenin positive. Mammary epithelium from the lymph node region of the fourth right mammary gland was analyzed from four rats per stage, with five representative fields analyzed per rat.

In vitro phagocytosis assay. Non-transformed murine mammary $\mathrm{EpH} 4$ cells were cultured in DMEM with high glucose (Sigma-Aldrich, St. Louis, MO, USA), without L-glutamine or sodium pyruvate, with additives at the following final concentrations: 5\% FBS, $2 \mathrm{mM}$ L-glutamine, $10 \mathrm{mM} \mathrm{HEPES}$ and $100 \mathrm{units} / \mathrm{ml}$ each of penicillin and streptomycin (all additives from Hyclone, Logan, UT, USA). In order to promote junctional integrity before use in phagocytosis assays, cells were maintained as confluent monolayers split 1:3 every 5-7 days with daily media changes. For phagocytosis assays, $70000 \mathrm{EpH} 4$ cells were plated in complete medium onto $0.4 \mu \mathrm{m}$ filters (BD Biosciences, San Jose, CA, USA) in a 24-well format with the media changed daily. Cells were cultured for $\sim 7$ days, to allow for the formation of a monolayer with intact cell junctions. To monitor integrity of cell junctions, the TEER was measured daily, before changing the media. Once the TEER reached $300 \Omega^{*} \mathrm{~cm}^{2}$, complete medium was removed, cells were washed twice with phosphate buffered saline (PBS) and then treated with 1,3 or $5 \mathrm{ng} / \mathrm{ml}$ recombinant human (rh) TGF- $\beta 3,20$ or $40 \mathrm{mM} \mathrm{LiCl}$, or vehicle in serum-free

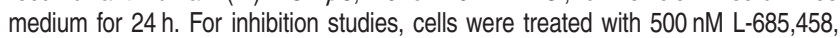
$20 \mu \mathrm{M}$ DAPT or $25 \mu \mathrm{M}$ iCRT3 simultaneously with $1 \mathrm{ng} / \mathrm{ml}$ TGF- $\beta 3$. TGF- $\beta 3$ and DAPT were purchased from R\&D Systems (Minneapolis, MN, USA), and LiCl, L-685,458 and iCRT3 were purchased from Sigma-Aldrich. After $24 \mathrm{~h}$, medium containing the treatment was removed and cells were washed twice with PBS. EpH4 monolayers were then incubated with the phagocytic target (either $10 \mu \mathrm{m}$ Fluoresbrite BB carboxylated latex microspheres/beads (Polysciences, Inc., Warrington, PA, USA) or apoptotic cells) for $4-6 \mathrm{~h}$, followed by washing three times with ice-cold PBS to remove bound, but unengulfed, beads or cells. EpH4 cell monolayers contain similar cell numbers across treatment conditions (data not shown); therefore, phagocytic index was quantified by multiplying the number of phagocytes by the average number of targets engulfed per phagocyte, with four 
fields analyzed per filter and three filters per condition per experiment. Results are reported as fold change compared with vehicle treatment due to variation in baseline phagocytosis levels across experiments.

Generation of apoptotic cells. $\mathrm{EpH} 4$ cells at $95 \%$ confluence were labeled with $1 \mu \mathrm{M}$ CellTracker Red CMPTX (Molecular Probes, Life Technologies, Grand Island, NY, USA) at $37^{\circ} \mathrm{C}$ for $30 \mathrm{~min}$. Following labeling, apoptosis was induced in EpH4 cells by subculturing 1:2 into apoptosis induction media (DMEM high-glucose base media with no L-glutamine or sodium pyruvate, plus $1 \% 1 \mathrm{M} \mathrm{HEPES}$ and $1 \%$ pen/strep) at $37^{\circ} \mathrm{C}$ for $16 \mathrm{~h}$. After $16 \mathrm{~h}$, the percent live, apoptotic and necrotic cells in the preparation was quantified by morphological criteria and trypan blue exclusion. Live cells were rounded with no evidence of apoptotic morphology and trypan blue negative, apoptotic cells were those with blebbing or apoptotic nuclei and trypan blue negative, and necrotic cells were those that were trypan blue positive.

Immunocytochemistry of mammary epithelial cells in culture. EpH4 cell monolayers on transwell filters were fixed in $4 \%$ paraformaldehyde for $15 \mathrm{~min}$ and permeabilized using $0.5 \%$ Triton X-100 (Sigma-Aldrich). Fixed cells on filters were then incubated sequentially at RT with $1.1 \mathrm{M}$ glycine for $5 \mathrm{~min}$ to quench autofluorescence, $20 \mathrm{mg} / \mathrm{ml}$ bovine serum albumin for $1 \mathrm{~h}$ to block nonspecific protein interactions and with primary and secondary antibodies (Supplemental Table S2) for 60 and $30 \mathrm{~min}$, respectively. Filters were then removed from transwells with a scalpel and mounted onto slides using Prolong Gold Antifade Reagent with DAPI (Life Technologies).

$\gamma$-Secretase activity assay. For measurement of $\gamma$-secretase activity in mammary gland tissue lysates, rat mammary tissue with the lymph node removed was pulverized in liquid nitrogen and $50 \mathrm{mg}$ per rat was homogenized in $400 \mu$ l of assay buffer ( $50 \mathrm{mM}$ Tris- $\mathrm{HCl} \mathrm{pH} 6.8,2 \mathrm{mM}$ EDTA acid, $0.25 \%$ CHAPSO). Protein concentrations were determined using Bio-Rad Protein Assay Dye Reagent (Hercules, CA, USA). Ten micrograms of total protein and $8 \mu \mathrm{M}$ fluorogenic $\gamma$-secretase substrate (Merck Millipore, Billerica, MA, USA) were incubated in assay buffer in a final reaction volume of $150 \mu \mathrm{l}$ for $5 \mathrm{~h}$ at $37^{\circ} \mathrm{C}$. After incubation, reactions were centrifuged at $16100 \times g$ for $15 \mathrm{~min}$ at $4^{\circ} \mathrm{C}$. Supernatant was transferred to a black-walled 96-well plate (Thermo Scientific, Waltham, MA, USA) and fluorescence was measured at excitation wavelength of $360 / 40 \mathrm{~nm}$ and emission wavelength of $460 / 40 \mathrm{~nm}$ using a BioTek Synergy 2 (Winooski, VT, USA). To account for differences in cellular content in the mammary tissue from lactation to involution day 6 , fluorescence was normalized to glyceraldehyde 3-phosphate dehydrogenase (GAPDH) level in homogenized mammary tissue samples as determined by immunoblotting (Supplementary Figure S1). For immunoblotting, $15 \mu \mathrm{g}$ of mammary tissue lysate homogenized in $\gamma$-secretase activity assay buffer was separated by SDS-polyacrylamide gel electrophoresis (SDS-PAGE) using a 10\% acrylamide gel. Immunoblotting using rabbit-anti-GAPDH (Sigma-Aldrich; $1 \mathrm{~h}, \mathrm{RT})$ and densitometry were performed as described below.

Immunoblotting and quantification. Pooled rat mammary tissue lysates were prepared as described ( $n=6$ animals/reproductive group). ${ }^{22} \mathrm{EpH} 4$ cell lysates were prepared by collecting cells directly into $100 \mu \mathrm{l}$ radioimmunoprecipitation assay buffer $(10 \mu \mathrm{M}$ Tris pH 7.4, $150 \mu \mathrm{M} \mathrm{NaCl}, 0.1 \%$ SDS, $1 \%$ sodium deoxycholate and $1 \%$ Triton $\mathrm{X}-100)$ containing protease and phosphatase inhibitors (1x Protease Inhibitor Cocktail (Sigma-Aldrich), $200 \mu \mathrm{g} / \mathrm{ml}$ phenylmethylsulfonyl fluoride, $1 \mathrm{mM}$ $\mathrm{Na}_{3} \mathrm{VO}_{4}$ and $50 \mathrm{mM} \mathrm{NaF}$ ). For TGF- $\beta$, samples were run under non-reducing conditions by preparing mammary tissue lysate samples in loading buffer containing $10 \%$ SDS, $50 \%$ glycerol, $0.4 \mathrm{M}$ Tris $\mathrm{pH} 6.8$ and $0.1 \% \mathrm{w} / \mathrm{v}$ bromophenol blue without reducing agents. Thirty microliters of total protein were separated by SDS-PAGE using a 10\% acrylamide gel. Membranes were blocked in $5 \%$ non-fat dry milk in Tris-buffered saline (10 mM Tris-HCl pH 8.0, $150 \mathrm{mM} \mathrm{NaCl}$ ) containing $0.1 \%$ Tween 20 for $1 \mathrm{~h}$ at RT. Immunoblotting was performed using mouse anti-bovine TGF- $\beta 1$, 2 and 3 (MAB1835, R\&D Systems; overnight, $4^{\circ} \mathrm{C}$ ), mouse anti-human E-cad (610181, BD Biosciences; overnight, $4^{\circ} \mathrm{C}$ ), rabbit anti-human PS-1 (ab65293, Abcam, Cambridge, MA, USA) or rabbit anti-mouse GAPDH (G9545, SigmaAldrich; $1 \mathrm{~h}, \mathrm{RT}$ ), followed by anti-mouse or anti-rabbit horseradish peroxidaseconjugated secondary antibody (Santa Cruz Biotechnologies, Santa Cruz, CA, USA, and Bio-Rad Laboratories, respectively; $30 \mathrm{~min}$, RT) with detection using Enhanced Chemiluminescence Western Blotting Substrate (Thermo Scientific). Densitometry was performed using ImageJ Software (http://imagej.nih.gov/ij/).

RNA isolation, cDNA synthesis and quantitative RT-PCR. Two hundred microliters of TRIzol Reagent (Life Technologies) were added to $\mathrm{EpH} 4$ cell monolayers per 24-well transwell filter immediately following removal of medium and samples were collected using a cell scraper modified to fit within the transwell filter. RNA was isolated as per the manufacturer's protocol and, to facilitate RNA precipitation, $10 \mu \mathrm{g}$ UltraPure glycogen (Life Technologies) was added per sample during the RNA precipitation. Resultant RNA was resuspended in $20 \mu \mathrm{l}$ nucleasefree water and RNA concentration determined using a NanoDrop 2000 UV-Vis Spectrophotometer (Thermo Scientific). Reverse-transcriptase reactions were performed using the iScript cDNA Synthesis Kit (Bio-Rad Laboratories) with $1 \mu \mathrm{g}$ total RNA. For quantitative RT-PCR, $1 \mu \mathrm{l}$ of reverse transcriptase reactions was combined with SYBR green (Bio-Rad Laboratories) and forward and reverse primers at a concentration of $1 \mu \mathrm{M}$ each, and brought up to a final reaction volume of $20 \mu \mathrm{l}$ with nuclease-free water. The following primers were used, from Integrated DNA Technologies (Coralville, lowa, USA): Psen1, forward: 5'-ACC TGC ACC TTT GTC CTA CTT CCA-3', reverse: 5'-TGT CAA GTC TCT GCC TGT CAT GCT-3'; Actb, forward: 5'-GCA ACG AGC GGT TCC G-3', reverse: 5'-CCC AAG AAG GAA GGC TGG A-3'; Cond1, forward: 5'-TAC CAT GGA GGG TGG GTT GGA AAT-3', reverse: 5'-TGC TGC AAA TGG AAC TGC TTC TGG-3'; axin2, forward: 5'-ACG CAC TGA CCG ACG ATT C-3', reverse: 5'-CCA TGC GGT AAG GAG GGA C-3'; and Tcf7, forward: 5'-AAG GTC ATT GCT GAG TGC ACA C-3', reverse: $5^{\prime}$-TGC ATG CCA CCT GCG AC-3'. Reactions were run using the following program: $3 \mathrm{~min}, 95^{\circ} \mathrm{C} ; 10 \mathrm{~s}, 95^{\circ} \mathrm{C} ; 1 \mathrm{~min}, 60^{\circ} \mathrm{C}$ (42 cycles); $1 \mathrm{~min}, 95^{\circ} \mathrm{C} ; 1 \mathrm{~min}$, $55^{\circ} \mathrm{C}$. Primer specificity was confirmed via melt-curve analysis. Data were collected using the MyiQ Single Color Real-Time PCR Detection System with iQ5 software (Bio-Rad Laboratories) and the Psen1 gene expression was normalized to actin using the $\Delta \Delta$ Ct method.

Microarray gene expression. Affymetrix Mouse Gene 1.1 ST Array Strips (Affymetrix, Santa Clara, CA, USA) were used to measure gene expression using the GeneAtlas system (Affymetrix). RNA was isolated from EpH4 cells using TRIzol Reagent (Life Technologies), as described above, and $250 \mathrm{ng}$ per sample was prepared for microarray analysis and hybridized using the Ambion WT Expression Kit (Life Technologies) and GeneChip WT Terminal Labeling Kit (Affymetrix), as per the manufacturer's protocol. Raw gene expression data was extracted and normalized by Robust Multiarray Average algorithm ${ }^{23}$ using Affymetrix Power Tools program. Microarray data has been deposited at the NCBI Gene Expression Omnibus under accession number GES62126.

Statistical analysis. Statistical analyses were performed using GraphPad Prism v.6 software (GraphPad Software, Inc., La Jolla, CA, USA), as indicated.

\section{Conflict of Interest}

The authors declare no conflict of interest.

Acknowledgements. We thank Peggy Neville for insightful discussion regarding mammary epithelial cell biology; Patricia Bell, Qiuchen Guo, Mona Hamermesh, Ethan Cabral, Hadley Holden and Eileen Engelberg for technical assistance; Sonali Jindal for pathologic review of human breast tissue, mannose receptor IHC and human TUNEL staining; Xiao-Jing Wang for insightful discussion and critical review of this manuscript; and Steven Anderson, Elizabeth Wellberg and Troy Schedin for assistance in performing gene array analysis. In addition, we thank the patients for their contribution to this research. This work was supported, in part, by the Department of Defense Predoctoral Training Award BC093130 to JF; the University of Colorado's NIH/NCI Tissue Biobanking and Processing Grant P30CA046934; the Department of Defense Breast Cancer Research Program Grant BC104000, the National Institute of Health Grant 5R01CA169175 and Safeway and Grohne Family Foundation Awards to PS and VB; and by grant HL114381 to P.M. Imaging was performed in the University of Colorado Advanced Light Microscopy Core Facility supported in part by NIH/NCATS Colorado CTSI grant number UL1 TR001082.

1. Walker NI, Bennett RE, Kerr JF. Cell death by apoptosis during involution of the lactating breast in mice and rats. Am J Anat 1989; 185: 19-32.

2. Monks J, Smith-Steinhart C, Kruk ER, Fadok VA, Henson PM. Epithelial cells remove apoptotic epithelial cells during post-lactation involution of the mouse mammary gland. Biol Reprod 2008; 78: 586-594.

3. Elliott MR, Ravichandran KS. Clearance of apoptotic cells: implications in health and disease. J Cell Biol 2010; 189: 1059-1070. 
4. Sandahl M, Hunter DM, Strunk KE, Earp HS, Cook RS. Epithelial cell-directed efferocytosis in the post-partum mammary gland is necessary for tissue homeostasis and future lactation. BMC Dev Biol 2010; 10: 122.

5. Teplova I, Lozy F, Price S, Singh S, Barnard N, Cardiff RD et al. ATG proteins mediate efferocytosis and suppress inflammation in mammary involution. Autophagy 2013; 9: 459-475.

6. Nguyen DA, Neville MC. Tight junction regulation in the mammary gland. J Mammary Gland Biol Neoplasia 1998; 3: 233-246.

7. Vallorosi CJ, Day KC, Zhao X, Rashid MG, Rubin MA, Johnson KR et al. Truncation of the beta-catenin binding domain of $\mathrm{E}$-cadherin precedes epithelial apoptosis during prostate and mammary involution. J Biol Chem 2000; 275: 3328-3334.

8. Faure E, Heisterkamp N, Groffen J, Kaartinen V. Differential expression of TGF-beta isoforms during postlactational mammary gland involution. Cell Tissue Res 2000; 300: 89-95.

9. Atwood CS, Ikeda M, Vonderhaar BK. Involution of mouse mammary glands in whole organ culture: a model for studying programmed cell death. Biochem Biophys Res Commun 1995; 207: 860-867.

10. Nguyen AV, Pollard JW. Transforming growth factor beta3 induces cell death during the first stage of mammary gland involution. Development 2000; 127: 3107-3118.

11. Schedin P, O'Brien J, Rudolph M, Stein T, Borges V. Microenvironment of the involuting mammary gland mediates mammary cancer progression. J Mammary Gland Biol Neoplasia 2007; 12: 71-82.

12. Gorska AE, Jensen RA, Shyr $Y$, Aakre ME, Bhowmick NA, Moses HL. Transgenic mice expressing a dominant-negative mutant type II transforming growth factor-beta receptor exhibit impaired mammary development and enhanced mammary tumor formation. Am J Pathol 2003; 163: 1539-1549.

13. Yang YA, Tang B, Robinson G, Hennighausen L, Brodie SG, Deng CX et al. Smad3 in the mammary epithelium has a nonredundant role in the induction of apoptosis, but not in the regulation of proliferation or differentiation by transforming growth factor-beta. Cell Growth Differ 2002; 13: 123-130.

14. Bierie B, Stover DG, Abel TW, Chytil A, Gorska AE, Aakre M et al. Transforming growth factor-beta regulates mammary carcinoma cell survival and interaction with the adjacent microenvironment. Cancer Res 2008; 68: 1809-1819.

15. Flanders KC, Wakefield LM. Transforming growth factor-(beta)s and mammary gland involution; functional roles and implications for cancer progression. J Mammary Gland Biol Neoplasia 2009; 14: 131-144.

16. van der Zee E, Everts V, Hoeben K, Beertsen W. Cytokines modulate phagocytosis and intracellular digestion of collagen fibrils by fibroblasts in rabbit periosteal explants. Inverse effects on procollagenase production and collagen phagocytosis. J Cell Sci 1995; 108: 3307-3315.

17. Bauer T, Zagórska A, Jurkin J, Yasmin N, Köffel R, Richter S et al. Identification of Axl as a downstream effector of TGF- $\beta 1$ during Langerhans cell differentiation and epidermal homeostasis. J Exp Med 2012; 209: 2033-2047.

18. Sheu SJ, Sakamoto T, Osusky R, Wang HM, Ogden TE, Ryan SJ et al. Transforming growth factor-beta regulates human retinal pigment epithelial cell phagocytosis by influencing a protein kinase C-dependent pathway. Graefes Arch Clin Exp Ophthalmol 1994; 232: 695-701.

19. Tian YC, Phillips AO. Interaction between the transforming growth factor-beta type II receptor/Smad pathway and beta-catenin during transforming growth factor-beta1-mediated adherens junction disassembly. Am J Pathol 2002; 160: 1619-1628.

20. Fornetti J, Jindal S, Middleton KA, Borges VF, Schedin P. Physiological COX-2 expression in breast epithelium associates with COX-2 levels in ductal carcinoma in situ and invasive breast cancer in young women. Am J Pathol 2014; 184: 1219-1229.

21. Figueroa JD, Flanders KC, Garcia-Closas M, Anderson WF, Yang XR, Matsuno RK et al. Expression of TGF-beta signaling factors in invasive breast cancers: relationships with age at diagnosis and tumor characteristics. Breast Cancer Res Treat 2010; 121: 727-735.

22. Schedin $\mathrm{P}$, Mitrenga $\mathrm{T}, \mathrm{McD}$ aniel $\mathrm{S}$, Kaeck M. Mammary ECM composition and function are altered by reproductive state. Mol Carcinog 2004; 41: 207-220.

23. Irizarry RA, Hobbs B, Collin F, Beazer-Barclay YD, Antonellis KJ, Scherf U et al. Exploration, normalization, and summaries of high density oligonucleotide array probe level data. Biostatistics 2003; 4: 249-264.

24. Gazi U, Martinez-Pomares $L$. Influence of the mannose receptor in host immune responses. Immunobiology 2009; 214: 554-561.

25. Marshall A, Pai V, Sartor M, Horseman N. In vitro multipotent differentiation and barrier function of a human mammary epithelium. Cell Tissue Res 2009; 335: 383-395.

26. Nguyen DA, Parlow AF, Neville MC. Hormonal regulation of tight junction closure in the mouse mammary epithelium during the transition from pregnancy to lactation. $J$ Endocrinol 2001; 170: 347-356.

27. Erwig L-P, McPhilips KA, Wynes MW, Ivetic A, Ridley AJ, Henson PM. Differential regulation of phagosome maturation in macrophages and dendritic cells mediated by Rho GTPases and ezrin-radixin-moesin (ERM) proteins. Proc Natl Acad Sci 2006; 103: 12825-12830.

28. Tosello-Trampont A-C, Brugnera E, Ravichandran KS. Evidence for a conserved role for Crkll and Rac in engulfment of apoptotic cells. J Biol Chem 2001; 276: 13797-13802.

29. Kolek O, Gajkowska B, Godlewski MM, Motyl T. Antiproliferative and apoptotic effect of TGFbeta 1 in bovine mammary epithelial BME-UV1 cells. Comp Biochem Physiol C Toxicol Pharmacol 2003; 134: 417-430.
30. Xu J, Lamouille S, Derynck R. TGF-beta-induced epithelial to mesenchymal transition. Cell Res 2009; 19: 156-172.

31. Wolfe MS. Toward the structure of presenilin/gamma-secretase and presenilin homologs. Biochim Biophys Acta 2013; 1828: 2886-2897.

32. Clarkson R, Wayland M, Lee J, Freeman T, Watson C. Gene expression profiling of mammary gland development reveals putative roles for death receptors and immune mediators in post-lactational regression. Breast Cancer Res 2004; 6: R92-R109.

33. Stein T, Morris J, Davies C, Weber-Hall S, Duffy M-A, Heath V et al. Involution of the mouse mammary gland is associated with an immune cascade and an acute-phase response, involving LBP, CD14 and STAT3. Breast Cancer Res 2004; 6: R75-R91.

34. Hebert SS, Godin C, Tomiyama T, Mori H, Levesque G. Dimerization of presenilin-1 in vivo: suggestion of novel regulatory mechanisms leading to higher order complexes. Biochem Biophys Res Commun 2003; 301: 119-126.

35. Ratovitski T, Slunt HH, Thinakaran G, Price DL, Sisodia SS, Borchelt DR. Endoproteolytic processing and stabilization of wild-type and mutant presenilin. J Biol Chem 1997; 272: 24536-24541.

36. Dovey HF, John V, Anderson JP, Chen LZ, de Saint Andrieu P, Fang LY et al. Functional gamma-secretase inhibitors reduce beta-amyloid peptide levels in brain. J Neurochem 2001; 76: 173-181.

37. Marambaud P, Shioi J, Serban G, Georgakopoulos A, Sarner S, Nagy V et al. A presenilin-1/ gamma-secretase cleavage releases the $\mathrm{E}$-cadherin intracellular domain and regulates disassembly of adherens junctions. EMBO J 2002; 21: 1948-1956.

38. Gonsalves FC, Klein K, Carson BB, Katz S, Ekas LA, Evans S et al. An RNAi-based chemical genetic screen identifies three small-molecule inhibitors of the Wnt/wingless signaling pathway. Proc Natl Acad Sci USA 2011; 108: 5954-5963.

39. Atabai K, Fernandez R, Huang X, Ueki I, Kline A, Li Y et al. Mfge8 is critical for mammary gland remodeling during involution. Mol Biol Cell 2005; 16: 5528-5537.

40. Berga SE. Electrical potentials and cell-to-cell dye movement in mouse mammary gland during lactation. Am J Physiol 1984; 247: C20-C25.

41. Gudey SK, Sundar R, Mu Y, Wallenius A, Zang G, Bergh A et al. TRAF6 stimulates the tumor-promoting effects of TGF\{beta\} type I receptor through polyubiquitination and activation of presenilin 1. Sci Signal 2014; 7: ra2.

42. Raurell I, Codina M, Casagolda D, Del Valle B, Baulida J, de Herreros AG et al. Gammasecretase-dependent and -independent effects of presenilin1 on beta-catenin.Tcf-4 transcriptional activity. PLOS One 2008; 3: e4080.

43. Sutherland C. What Are the bona fide GSK3 Substrates? Int J Alzheimers Dis 2011; 2011: 505607.

44. Van den Bossche J, Malissen B, Mantovani A, De Baetselier P, Van Ginderachter JA. Regulation and function of the E-cadherin/catenin complex in cells of the monocytemacrophage lineage and DCs. Blood 2012; 119: 1623-1633.

45. Bulloj A, Duan W, Finnemann SC. PI 3-kinase independent role for AKT in F-actin regulation during outer segment phagocytosis by RPE cells. Exp Eye Res 2013; 113: 9-18.

46. Koziel H. Rho GTPases in alveolar macrophage phagocytosis. Methods Enzymol 2008; 439 303-313.

47. Ren S, Zhang S, Li M, Huang C, Liang R, Jiang A et al. NF-kappaB p65 and c-Rel subunits promote phagocytosis and cytokine secretion by splenic macrophages in cirrhotic patients with hypersplenism. Int J Biochem Cell Biol 2013; 45: 335-343.

48. Baki L, Marambaud P, Efthimiopoulos S, Georgakopoulos A, Wen P, Cui W et al. Presenilin1 binds cytoplasmic epithelial cadherin, inhibits cadherin/p120 association, and regulates stability and function of the cadherin/catenin adhesion complex. Proc Natl Acad Sci USA 2001; 98: 2381-2386.

49. Thoreson MA, Anastasiadis PZ, Daniel JM, Ireton RC, Wheelock MJ, Johnson KR et al. Selective uncoupling of $\mathrm{p} 120$ (ctn) from E-cadherin disrupts strong adhesion. J Cell Biol 2000; 148: $189-202$

50. Dahl U, Sjodin A, Semb H. Cadherins regulate aggregation of pancreatic beta-cells in vivo. Development 1996; 122: 2895-2902.

51. Delmas V, Pla P, Feracci H, Thiery JP, Kemler R, Larue L. Expression of the cytoplasmic domain of E-cadherin induces precocious mammary epithelial alveolar formation and affects cell polarity and cell-matrix integrity. Dev Biol 1999; 216: 491-506.

52. Schedin P, Mitrenga T, Kaeck M. Estrous cycle regulation of mammary epithelial cell proliferation, differentiation, and death in the sprague-dawley rat: a model for investigating the role of estrous cycling in mammary carcinogenesis. J Mammary Gland Biol Neoplasia 2000; 5: 211-225.

53. Brown LF, Guidi AJ, Schnitt SJ, Van De Water L, Iruela-Arispe ML, Yeo T-K et al. Vascular stroma formation in carcinoma in situ, invasive carcinoma, and metastatic carcinoma of the breast. Clin Cancer Res 1999; 5: 1041-1056.

54. Guidi AJ, Schnitt SJ, Fischer L, Tognazzi K, Harris JR, Dvorak HF et al. Vascular permeability factor (vascular endothelial growth factor) expression and angiogenesis in patients with ductal carcinoma in situ of the breast. Cancer 1997; 80: 1945-1953.

55. Lagios MD. Classification of duct carcinoma in situ (DCIS) with a characterization of high grade lesions: defining cohorts for chemoprevention trials. J Cell Biochem Suppl 1996; 25: 108-111.

56. Guo HQ, Zhang ZH, Zhao H, Zhao LL, Pan QJ. Recognizing breast ductal carcinoma in situ on fine-needle aspiration: a diagnostic dilemma. Diagn Cytopathol 2013; 41: 710-715.

57. Provenzano PP, Inman DR, Eliceiri KW, Knittel JG, Yan L, Rueden CT et al. Collagen density promotes mammary tumor initiation and progression. BMC Med 2008; 6: 11. 
58. Fornetti J, Martinson $\mathrm{H}$, Borges $\mathrm{V}$, Schedin $\mathrm{P}$. Emerging targets for the prevention of pregnancy-associated breast cancer. Cell Cycle 2012; 11: 639-640.

59. Fornetti J, Martinson HA, Betts CB, Lyons TR, Jindal S, Guo Q et al. Mammary gland involution as an immunotherapeutic target for postpartum breast cancer. J Mammary Gland Biol Neoplasia 2014; 19: 213-228.

60. Callihan EB, Gao D, Jindal S, Lyons TR, Manthey E, Edgerton S et al. Postpartum diagnosis demonstrates a high risk for metastasis and merits an expanded definition of pregnancyassociated breast cancer. Breast Cancer Res Treat 2013; 138: 549-559.

61. Schedin P. Pregnancy-associated breast cancer and metastasis. Nat Rev Cancer 2006; 6 : 281-291.

62. Martinson HA, Jindal S, Durand-Rougely C, Borges VF, Schedin P. Wound healing-like immune program facilitates postpartum mammary gland involution and tumor progression. Int J Cancer 2015; 136: 1803-1813.

63. Stanford JC, Young C, Hicks D, Owens P, Williams A, Vaught DB et al. Efferocytosis produces a prometastatic landscape during postpartum mammary gland involution. J Clin Invest 2014; 124: 4737-4752.

64. Fadok VA, Bratton DL, Frasch SC, Warner ML, Henson PM. The role of phosphatidylserine in recognition of apoptotic cells by phagocytes. Cell Death Differ 1998; 5: 551-562.

65. Freire-de-Lima CG, Xiao YQ, Gardai SJ, Bratton DL, Schiemann WP, Henson PM. Apoptotic cells, through transforming growth factor-beta, coordinately induce anti-inflammatory and suppress pro-inflammatory eicosanoid and NO synthesis in murine macrophages. J Biol Chem 2006; 281: 38376-38384.
66. Voll RE, Herrmann M, Roth EA, Stach C, Kalden JR, Girkontaite I. Immunosuppressive effects of apoptotic cells. Nature 1997; 390: 350-351.

67. Tavazoie SF, Alarcon C, Oskarsson T, Padua D, Wang Q, Bos PD et al. Endogenous human microRNAs that suppress breast cancer metastasis. Nature 2008; 451: 147-152.

68. Schlegel J, Sambade MJ, Sather S, Moschos SJ, Tan AC, Winges A et al. MERTK receptor tyrosine kinase is a therapeutic target in melanoma. J Clin Invest 2013; 123: 2257-2267.

69. Wang Y, Moncayo G, Morin Jr P, Xue G, Grzmil M, Lino MM et al. Mer receptor tyrosine kinase promotes invasion and survival in glioblastoma multiforme. Oncogene 2013; 32: 872-882.

(c) (i) $(9)$ This work is licensed under a Creative Commons Attribution-NonCommercial-NoDerivs 4.0 International License. The images or other third party material in this article are included in the article's Creative Commons license, unless indicated otherwise in the credit line; if the material is not included under the Creative Commons license, users will need to obtain permission from the license holder to reproduce the material. To view a copy of this license, visit http://creativecommons.org/licenses/by-nc-nd/4.0/

Supplementary Information accompanies this paper on Cell Death and Differentiation website (http://www.nature.com/cdd) 